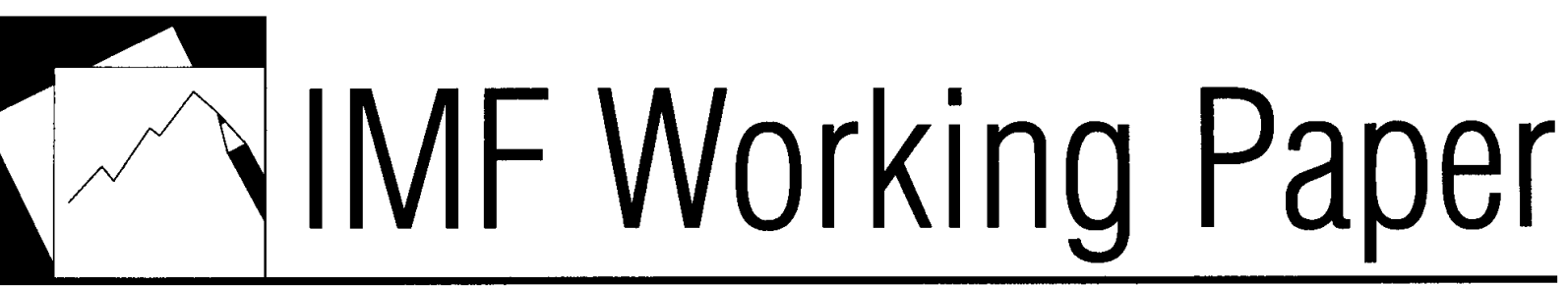

\title{
Inflation and Conflict in Iraq: The Economics of Shortages Revisited
}

David A.Grigorian and Udo Kock 


\title{
IMF Working Paper
}

Middle East and Central Asia Department

\section{Inflation and Conflict in Iraq: The Economics of Shortages Revisited}

\section{Prepared by David A. Grigorian and Udo Kock ${ }^{1}$}

\author{
Authorized for distribution by Enrique Gelbard
}

July 2010

\begin{abstract}
This Working Paper should not be reported as representing the views of the IMF.

The views expressed in this Working Paper are those of the author(s) and do not necessarily represent those of the IMF or IMF policy. Working Papers describe research in progress by the author(s) and are published to elicit comments and to further debate.

Containing inflation has turned out to be one of the most challenging aspects of economic management in Iraq. This paper posits that conventional as well as unconventional factors explain inflation dynamics in the recent past. We build a theoretical model based on the insights into the workings of socialist economies under supply shortages provided by Shleifer and Vishny (1992) to help explain price dynamics. In the model, strategic behavior of the fuel distribution monopolist results in fuel shortages, with implications for fuel and non-fuel inflation. A number of step-wise adjustments of administered prices for fuel products since December 2005 offer an interesting experiment to help study this behavior. Our findings show that inflation may have been influenced by shortages in fuel and non-fuel commodity supplies, which themselves are driven by violence and rent-seeking.
\end{abstract}

JEL Classification Numbers:E31, E65, P31

Keywords: Iraq, inflation, shortages, strategic behavior Author's E-Mail Address: dgrigorian@imf.org; ukock@imf.org

\footnotetext{
${ }^{1}$ We thank Adam Bennett, Enrique Gelbard, Adnan Mazarei, Ron van Rooden, Colin Rowat, Erik de Vrijer, and participants at the $8^{\text {th }}$ International Conference of the Middle East Economic Association (MEEA), in Nice, France for helpful comments and suggestions, and Carina Hreib for editorial assistance.
} 


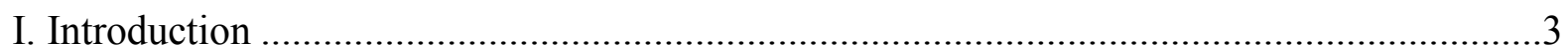

II. Background: Inflation, Oil Sector Governance, and Violence......................................4

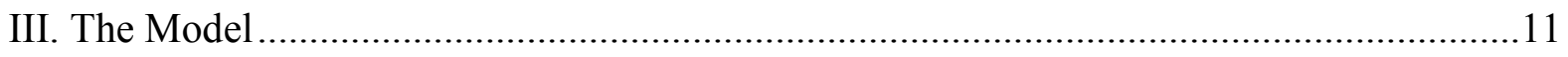

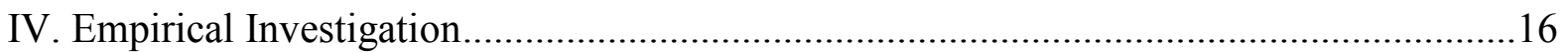

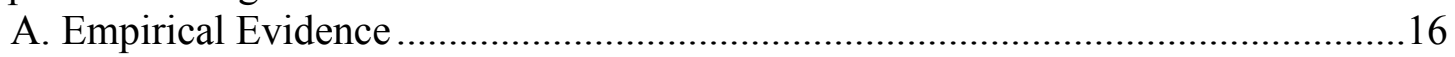

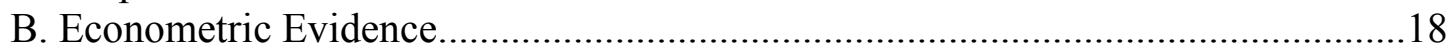

V. Conclusions and Policy Implications ..................................................................21

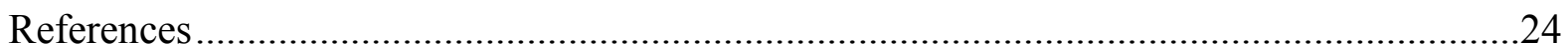

TABLES

1. Annual Consumer Price Inflation; ...............................................................................

2. Black Market and Official Fuel Prices, 2006-07.........................................................

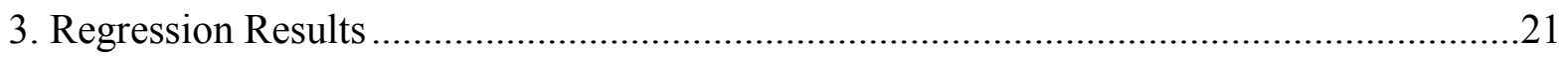

Figures

1. CPI, Core CPI, and Fuel Price Index, March 2004-December 2007 .................................5

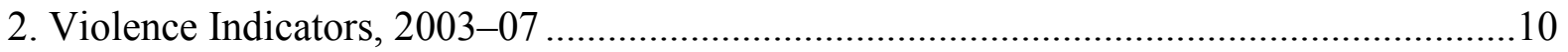

3. Violence and Inflation, August 2004-December 2007 ............................................. 11

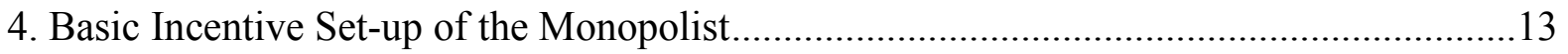

5. Response to Administered Price Adjustments .................................................................... 14

6. Limits of Administered Price Adjustments..................................................................... 15

7. International and Iraqi Black Market Prices for Gasoline ............................................. 17

8. Prices and Quantities of Regular Gasoline ............................................................... 18

\section{APPENDIX}

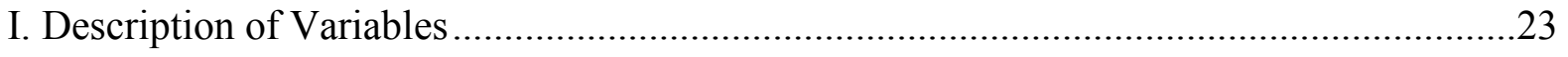




\section{INTRODUCTION}

After the invasion in March 2003 Iraq suffered from a prolonged period of very high inflation, which ended in late 2008 when inflation was brought under control. Containing high inflation has turned out to be one of the most challenging aspects of managing Iraq's economy in recent years. The persistent violence, commodity shortages, pervasive dollarization, a weak monetary transmission mechanism, and lack of data all contributed to the difficulties in designing and implementing policies to bring high inflation down. Against this background we argue that rent-seeking behavior in the oil sector and violence were key contributing factors to the surge in inflation and can also help explain some of the stylized facts about inflation characteristics in Iraq since 2003.

We build a theoretical model based on the insights into the workings of socialist economies under supply shortages provided by Shleifer and Vishny (1992). In our model, the strategic behavior of the oil sector distribution monopoly results in fuel shortages, with implications for fuel and non-fuel inflation. The adjustment of administered prices for fuel products that took place in 2005 and 2007 offer an interesting experiment to help study this behavior. ${ }^{2}$ While these adjustments were intended to gradually eliminate direct budgetary subsidies and reduce smuggling, they also had implications for inflation through the black market premia for fuel products. While the latter increased in the first half of 2006, they leveled off thereafter and black market premia relative to official prices declined. ${ }^{3}$ The predictions of the model are confirmed by the econometric estimation of the inflation equation using data for 2003-07.

One caveat is in order here. Our efforts to analyze the underlying inflation trend are hampered by data limitations that prevent estimating the deviations from, and adjustment toward, long-run values of fundamentals. For example, one factor that that we are unable to appropriately account for is the movements in the equilibrium real exchange rate that has likely appreciated because of the terms-of-trade improvements observed during the period under review. ${ }^{4}$

\footnotetext{
${ }^{2}$ Starting in December 2005, with further adjustments in the second half of 2006 and in 2007, the price of regular gasoline has been increased from less than 3 U.S. dollar cents per liter to 32 U.S. dollar cents per liter, above the average in other oil-exporting countries in the region. Similar price adjustments have also been implemented for premium gasoline, diesel, LPG, and kerosene.

${ }^{3}$ The average ratio of black market to administered prices declined from approximately 4.3 following the December 2005 adjustment to 2.8 following the January 2007 adjustment.

${ }^{4}$ The price developments described throughout the paper took place against the background of a significant improvement in Iraq's terms of trade. From January 2004 through March 2007 the price of Iraq's crude oil increased by 92 percent from $\$ 26.4$ per barrel to $\$ 50.6$ per barrel. This improvement in the terms of tradereflected in the government's ability to sustain a higher level of domestic spending - has most likely resulted in an appreciation of the equilibrium real exchange rate. With the nominal exchange rate more or less constant to the U.S. dollar between late 2003 and late 2006, the adjustment of the actual real exchange rate to its equilibrium would have occurred via a gradual catching up in the Iraqi price level, generating a trend underlying rate of inflation. Because it is hard to estimate the equilibrium real exchange rate, or model the adjustment process, it is difficult to gauge how much of Iraq's underlying inflation during 2003-Q1 2007 derived from this process.
} 
The paper is structured in the following way. Section II discusses recent inflation developments in Iraq and the policy response to bring inflation down. From the picture that emerges we derive four stylized facts about recent inflation developments in Iraq. Section III discusses the links between commodity shortages, violence, and inflation, and presents a model that explains how rent-seeking in the oil sector can lead to shortages and subsequently inflation. ${ }^{5}$ Section IV presents the empirical investigation. Section V concludes and offers some policy recommendations.

\section{BACKGRound: Inflation, OIL SECTOR GOVERnANCE, AND ViolenCE}

\section{Inflation}

Maintaining macroeconomic stability while at the same time rebuilding oil infrastructure were key policy objectives in Iraq after the invasion in March 2003. To achieve these objectives the Coalition Provisional Authority (CPA) and two consecutive Iraqi governments attempted to control current government spending so as to limit inflationary pressures on small non-oil economy and to make room in the budget for reconstruction spending, in particular for the oil sector. A stable exchange rate was to serve as an anchor for monetary policy. It was envisaged that these policies would be able to keep inflation in the single digits in 2004 and at 15 percent and 12 percent in 2005 and 2006, respectively (IMF, 2007). Inflation turned out to be much higher than projected, reaching 65 percent by end-2006 (Table 1). ${ }^{6}$

It appears that a large part of the variance of the headline inflation rate since 2003 derives from the volatile behavior of energy and transportation prices (Figure 1). Throughout most of 2004 and 2005, headline inflation moved broadly in line with core inflation (which excludes energy and transportation). Starting in late 2005, fuel prices began to fluctuate strongly, with a steep upward trend. ${ }^{7}$ In 2006, however, the gap between core and headline inflation widened substantially, with fuel prices rising by 262 percent. This jump in fuel prices pushed up overall consumer price inflation to 65 percent while core inflation remained relatively stable at 32 percent. In the course of the first quarter of 2007, both core and headline inflation came down, while the difference between the two inflation measures narrowed.

\footnotetext{
${ }^{5}$ Inflation refers to both off-equilibrium price increases (captured in the model by shortages) as well as increases in the equilibrium price level (captured in the model by violence, a proxy for expectations of future policy changes).

${ }^{6}$ Historically, Iraq is not a high-inflation country. Foote, Block, and Gray (2004) point out that between 1945 and 1989 inflation usually stayed in the single digits. Only after the first Gulf war and the following UN Embargo did inflation surge to nearly 500 percent, as the government began to monetize its fiscal deficits.

${ }^{7}$ The Iraqi Consumer Price Index includes (black) market fuel prices, in addition to the official fuel prices.
} 
Table 1. Annual Consumer Price Inflation;

Projections and Realizations, 2004-2007

\begin{tabular}{lrrrr}
\hline & 2004 & 2005 & 2006 & 2007 \\
\hline $\begin{array}{l}\text { Projection } \\
\text { Sept. 2004 }\end{array}$ & 7 & 15 & 12 & 10 \\
July 2005 & -- & 20 & 12 & 10 \\
Dec. 2005 & -- & 20 & 15 & 10 \\
July 2006 & -- & -- & 30 & 17 \\
March 2007 & -- & -- & -- & 30 \\
July 2007 & -- & -- & -- & 30 \\
Actual & 31.7 & 31.6 & 64.8 & 4.7 \\
& & & & \\
\hline
\end{tabular}

Source: IMF, 2007.

Figure 1. CPI, Core CPI, and Fuel Price Index, March 2004-December 2007

(March 2004=100)

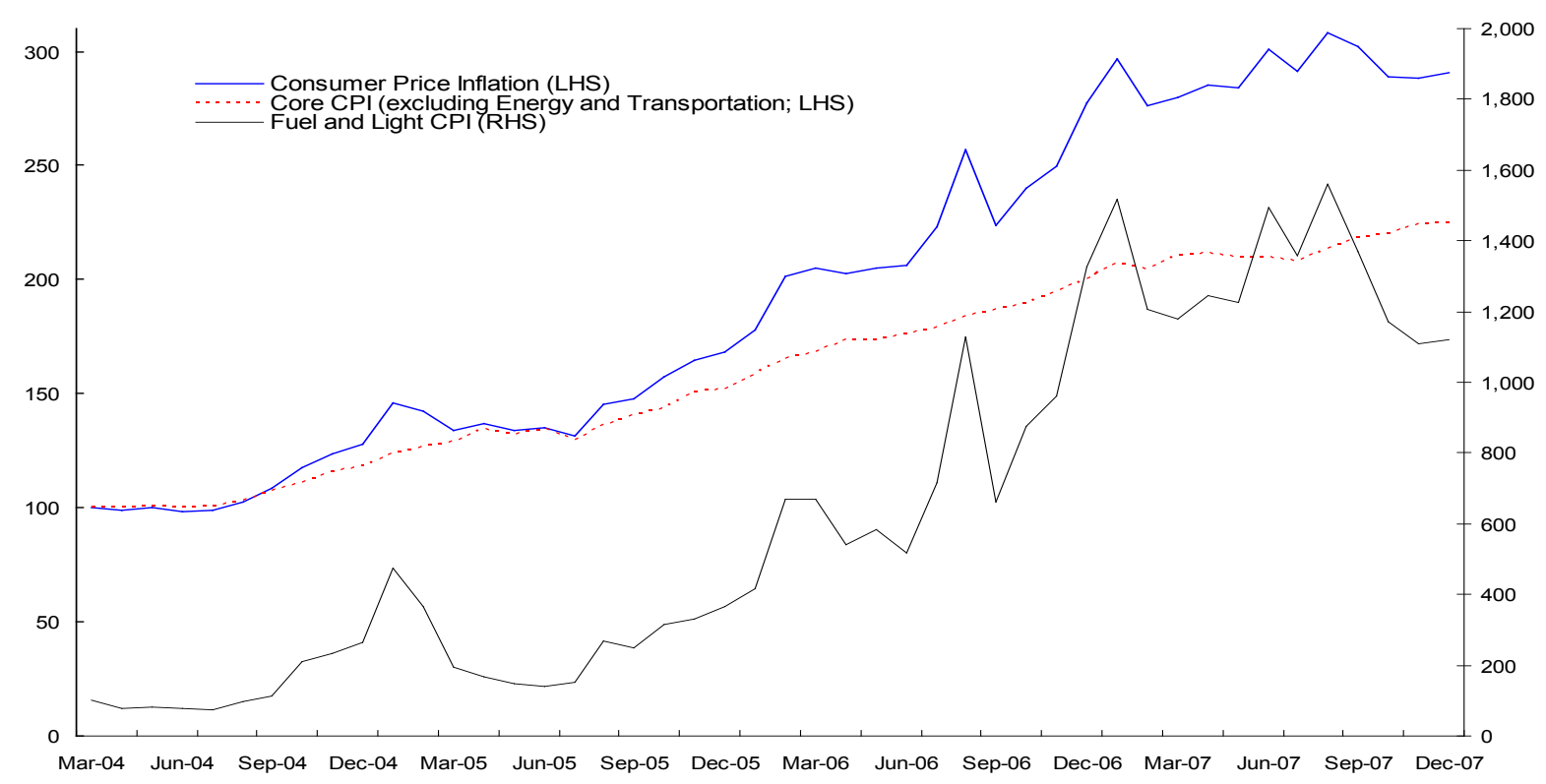


The Iraqi economy during this period was largely based on cash transactions, with both Iraqi dinars and U.S. dollars in us. After growing by 175 percent in 2004, Iraqi dinars in circulation registered a mere 18 percent growth in 2006. Given that real non-oil aggregate activity was on the rise and that price increases had not slowed down, inflation was likely accommodated by a disproportionate increase in availability of dollars in circulation, perhaps driven by expectations of devaluation. If so, the growth of dinar money supply would not be a good predictor of inflation as it would understate the extent of total (dinar plus dollar) money supply growth. (This hypothesis was supported by our estimation results reported below).

The acceleration in the rate of inflation during 2006 prompted the authorities to tighten monetary and exchange rate policies. In mid-November 2006 and early-January 2007, the Central Bank of Iraq (CBI) raised its policy interest rates in two steps to 20 percent. The exchange rate, which had been de facto pegged at around ID 1,460 to the U.S. dollar since May 2004, was allowed to appreciate in November 2006, resulting in a cumulative appreciation of 17 percent by December $2007 .{ }^{8}$ By offering a higher rate of return to dinar currency versus dollar currency via the gradual appreciation, the authorities hoped to counter the dollarization and strengthen the effectiveness of monetary policy. The appreciation would, at the same time, directly reduce imported inflation. The policy appeared to succeed in both increasing the demand for local currency and in reducing inflation: core inflation declined markedly throughout 2007 and headline inflation fell even sharper with a decline in violence and reduced shortages.

The pattern of inflation in Iraq since the invasion in 2003 until December 2007 can be summarized in the following stylized facts:

1. Core and headline inflation moved broadly in line with each other through 2005 , before the initiation of administered fuel price adjustments at the end of 2005 and the increase in violence in the first half of 2006; in 2006 the two measures of inflation diverged, with headline inflation increasingly above core inflation.

2. Following the introduction of the administered fuel price adjustments at end2005, black market prices for fuel products increased further, but remained below international levels.

3. The ratio of black market prices to administered prices (i.e., the black market premium) declined as administered prices were adjusted upwards.

\footnotetext{
8 The absence of noticeable pressures on the exchange rate in the period after the introduction of the new Iraqi Dinar (in 2003) is noteworthy. As King (2004) points out, “...the value of money depends on beliefs about the probability of survival of the institutions that define the state itself". Apparently, for most Iraqi's the survival of the post-Sadam state was never in doubt, despite the rising violence.
} 
4. While shortages of fuel products have gradually declined in 2007, they had not been eliminated by the end of the year. ${ }^{9}$

The rest of the paper attempts to explain these stylized facts.

\section{Oil Sector and supply of fuel products}

The Iraqi Ministry of Oil (MoO) has made efforts to increase crude oil available for domestic refining to increase the supply of fuel products. In the period 2005-2007 it managed to increase the supply of crude oil to refineries by about 50 percent. However, the efforts to increase the supply of fuel products were hampered by outdated refining infrastructure and violence. The government budgets made room for substantial investment in the oil and nonoil sectors, but violence and limited administrative capacity kept the rate of implementation of the investment budget low during 2005-2006. The resulting under-investment in the oil sector prevented a significant expansion in crude oil production and refining capacity of fuel products. ${ }^{10}$ Only towards the end of 2007 these efforts began to bear fruit and domestic usage increased to about 700,000 barrels per day, from 300,000-500,000 barrels per day throughout most of 2005-07. To help satisfy growing domestic demand for fuel products the government started importing fuel products. In 2005 and 2006 it spent ID 4.8 trillion (\$3.3 billion) and ID 4.1 trillion ( $\$ 2.8$ billion) on refined fuel product imports, respectively (IMF, 2007). ${ }^{11}$

$\mathrm{MoO}$ acts as both the manager and the regulator of the oil sector. One of the agencies under the umbrella of the $\mathrm{MoO}$ is the State Oil Marketing Organization (SOMO), which operates as a quasi-independent agency. In the absence of private sector oil distributors in Iraq, SOMO has been responsible for importing and distributing imported and domestically refined fuel products through the state-owned gas stations and storage facilities. ${ }^{12}$

Despite substantial government fuel imports, fuel shortages in 2006 were severe and widespread. A survey conducted by the United Kingdom's Department for International Development (DFID) in 2006 showed that queuing times at gas stations varied from 1-5 hours in Baghdad to more than 24 hours in some of the more remote districts. Some gas

\footnotetext{
${ }^{9}$ By February 2009 fuel shortages had been reduced significantly with only 32 percent of Iraqi's reporting fuel shortages in their neighborhood, compared to 81 percent in March 2008 (Source: BCC/ABC Iraq Poll, http://news.bbc.co.uk/2/shared/bsp/hi/pdfs/13_03_09_iraqpollfeb2009.pdf).

${ }^{10}$ The 2006 production plans of the Iraqi Ministry of Oil had envisaged refining 566 thousand barrels of crude oil per day to produce gasoline, kerosene, LPG and other fuel products. As it turned out only two thirds of that target was achieved (382 thousand barrels), with production as low as 38 percent of the target in some months. As a result, domestic production of fuel products also fell short of the targets. For gasoline and diesel only 70 percent of the production target was achieved, while for LPG it was 76 percent and for kerosene 56 percent.

${ }^{11}$ Some authors see the payout of large subsidies as a disciplinary device for public finances (Rowat, 2008). In countries where the government derives most of its revenues from rents (mostly from natural resources, as in the case of Iraq) instead of tax revenues, subsidies for virtually the entire population serve as a legitimate national dividend payout.

${ }^{12}$ A law was enacted in September 2006 to allow the private sector to import fuel. However, imports of private sector gasoline did not begin until late-2007.
} 
stations in the Kurdish north are believed to have only supplied gasoline to taxis. According to a BBC survey conducted in early 2007, 88 percent of Iraqis reported that the availability of "fuel for cooking or driving" was "quite bad" or "very bad". ${ }^{13}$ Shortages have been reported even in Baghdad's Green Zone, where senior Iraqi officials and diplomats reside. ${ }^{14}$ A report by the Inspector General (Office of the Inspector General, 2006) indicates that smuggling of refined fuel products to neighboring countries, corruption, mismanagement, and rent-seeking have all contributed to the prevailing shortages. While remaining noticeable throughout mid2007 shortages, however, declined toward the end of 2007.

With shortages becoming a daily fact of life in 2006, a flourishing black market developed for gasoline and other fuel products. Average black market prices for regular gasoline were ID 650 per liter (compared to an official price of ID 100 per liter), with prices in Baghdad around ID 600 per liter and prices in some of the outer governorates as high as ID 1,000 per liter (see DFID survey). By March 2007, the black market price for regular gasoline had increased further to about ID 740 per liter [compared to the (increased) official price of ID 300 per liter].

Table 2. Black Market and Official Fuel Prices, 2006-07 (in dinars per liter)

\begin{tabular}{lccc}
\hline & Black market price & Official price & $\begin{array}{l}\text { Percentage } \\
\text { difference }\end{array}$ \\
& & & \\
Regular Gasoline (unleaded) & 599 & 100 & 499 \\
First Quarter 2006 & 532 & 175 & 204 \\
Second Quarter 2006 & 811 & 175 & 364 \\
Third Quarter 2006 & 740 & 300 & 147 \\
First Quarter 2007 & & & \\
\hline
\end{tabular}

Source: DFID and Iraqi Ministry of Oil.

Widespread smuggling undermined the government's efforts to increase supply of fuel products. Even in March 2007, when official gasoline prices in Iraq had tripled to ID 300 per liter from ID 100 per liter in March 2006, the black market price was still about 40 percent lower than the market price in neighboring Jordan. Another factor that worked against the government's efforts to reduce shortages is that expansionary fiscal policies and an inflow of foreign currency increased demand for fuel products, which higher official fuel prices could not curtail.

\footnotetext{
${ }^{13}$ Iraq Poll 2007, BBC News.

14 “Even Green Zone Has It Own Fuel Crisis,” Azzaman newspaper, July 4, 2007.
} 


\section{Violence}

Violence has a direct impact on the ability of economic agents to produce and distribute goods. This effect is especially pronounced for fuel products, where there have been significant supply interruptions as a result of attacks on the oil sector infrastructure..$^{15}$ In particular, the northern crude oil export pipeline to Turkey was a frequent target and has been shut down due to insurgent attacks for most of 2006. In addition to three large refineries, the country has numerous small refineries and dozens of pumping stations and storage facilities, all of which are vulnerable to attack. The pipeline network for refined fuel products in Iraq stretches hundreds of miles. According to the MoO there were 186 attacks on oil installations in 2005, killing 47 oil engineers and 91 police and security guards. According to information collected by the Brookings Institution, oil installations were attacked on average twice a week during 2006 (see Figure 2).

Although more difficult to measure, other goods have also been in short supply as a result of the violence. According to the BBC survey, 62 percent of Iraqi respondents reported that availability of basic goods needed for their households was "bad", up from 38 percent in 2005 when the poll was last conducted. In the same period violence increased significantly.

Sustained violence could also affect agents' expectations and, as a result, their current behavior. It might shape expectations of the government's ability to maintain security, collect revenues, and secure macroeconomic stability, which in turn may offer insights to the future availability of basic commodities at predictable prices, the government's ability to close its fiscal gaps as well as the need to monetize the deficit.

The level and intensity of violence steadily increased in the sample period under review. In the second half of 2003 the average number of civilians killed per day was 17 . From mid2006, this number has more than quadrupled, while in the same period the number of bombings with multiple casualties increased from 7 per month to 57 per month. Underlying this rising trend in violence is significant variation in the timing and pattern of violence across different governorates in Iraq (Berman, Shapiro, and Felter, 2008).

\footnotetext{
${ }^{15}$ Because all operations of the oil sector are linked, a disruption in one part can shut down a different part of the oil infrastructure. For example, if the flow of fuel oil, a by-product from the refinery process, from the storage tanks to the power plants or the export terminals is interrupted, this not only interrupts electricity supply or fuel exports, but it also disrupts refinery operations and the domestic supply of gasoline because of capacity constraints of storage tanks for fuel oil.
} 
Figure 2. Violence Indicators, 2003-07
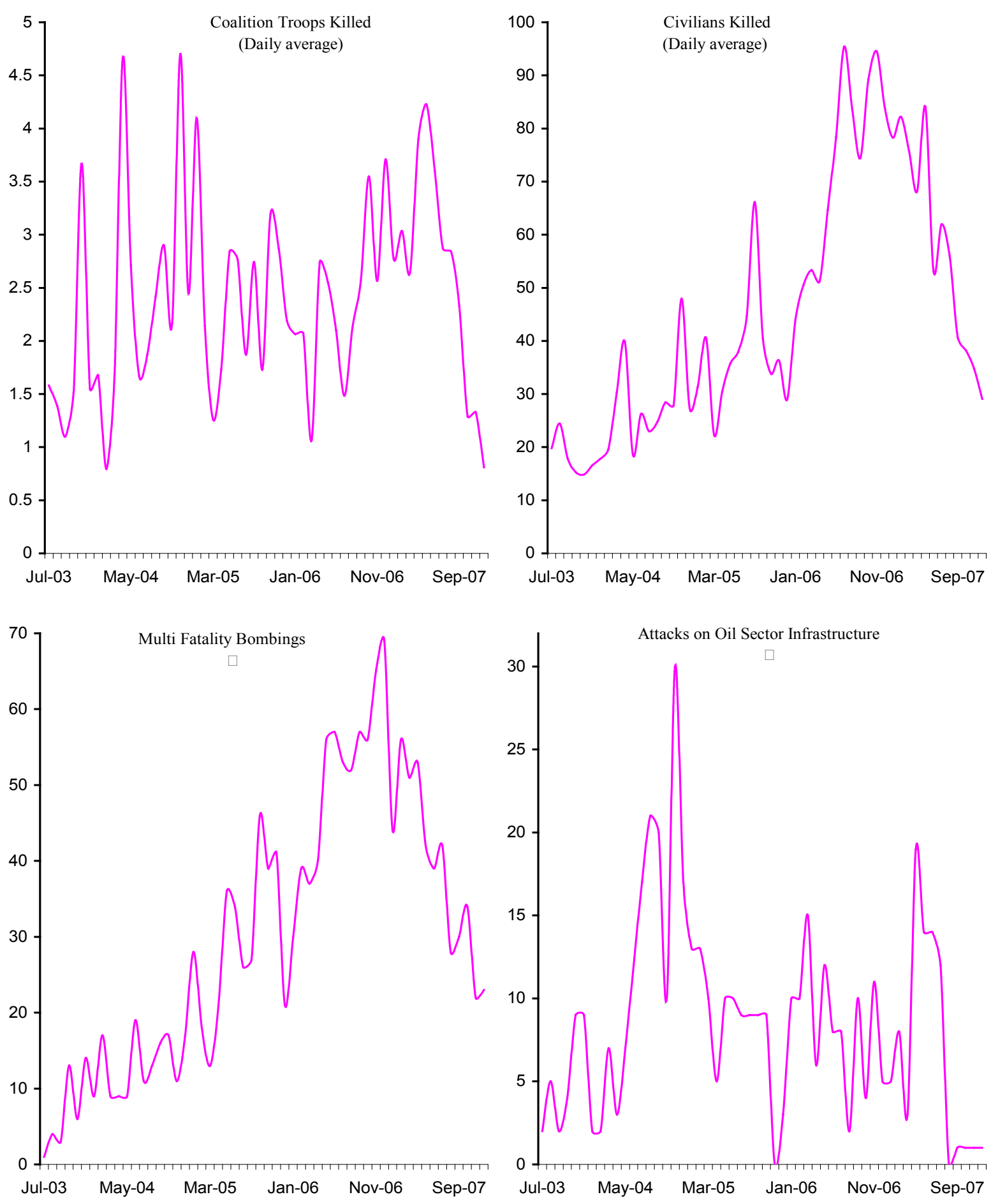

Source: Iraq Coalition Casualty Count, Iraq Body Count, Brookings Institution Iraq Index, and Iraq Pipeline Watch. 
Figure 3. Violence and Inflation, August 2004-December 2007

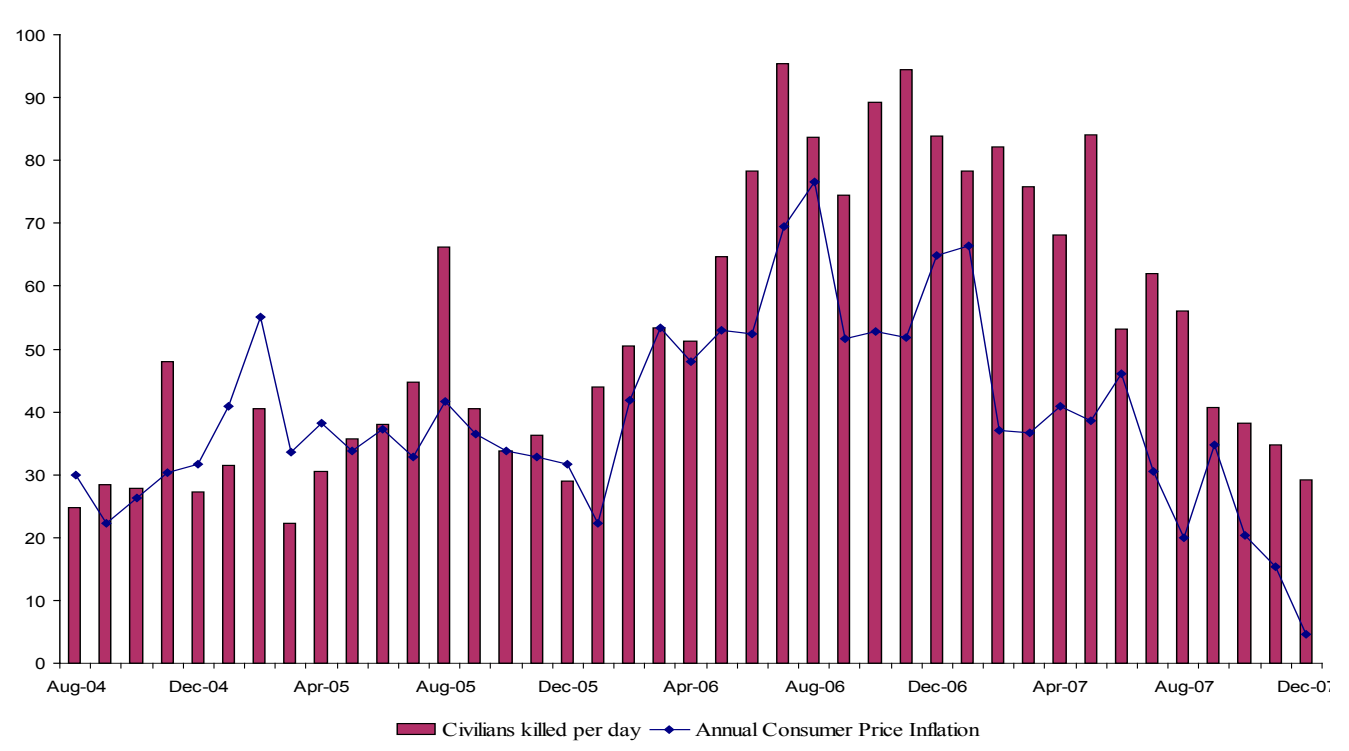

\section{THE MODEL}

The basic hypothesis behind the analysis is that rent-seeking behavior in oil distribution activities as well as severe and worsening security conditions could result in shortages of fuel products supplied and eventually create shortages on the market for non-oil goods, fueling inflation. The theoretical model is based on the insights into the workings of socialist economies under supply shortages provided by Shleifer and Vishny (1992). In Shleifer and Vishny's model, self-interested centralized planners-bureaucrats in the ministries and the managers of state owned enterprises - maximize the rents they extract from running the public sector. Since they cannot keep the official profits that the state-owned companies earn, they create shortages of output to collect rents from consumers. We apply this model to the situation in Iraq.

An important caveat is due here. Our model does not assume or suggest the presence of (institutionalized) rent-seeking behavior on the side of SOMO management. For the model to hold it would be sufficient if managers of individual gas stations, behave similarly to the central planners in Shleifer and Vishny's model. Instead of facing the country-wide demand for fuel as described in the model, these managers will face their own area-specific demand for fuel schedule and operate along their own marginal revenue schedule. This may also help explain why the different regions in Iraq faced shortages of various degrees and different black market premia.

As established by Lamont (1995), shortages cause gradual price adjustments and inflation, suggesting that disequilibrium could be an important part of the adjustment process of prices to shocks. Measuring shortages by simply observing price-quantity combinations, however, is not possible because supply and demand are not observable separately. One way to measure shortages would be to estimate the equilibrium relationship between prices and 
quantities in "tranquil times," and then define the shortage as the distance between the implied equilibrium quantities and the observed quantities. But this is not possible in Iraq's context of the time in question, which was anything but tranquil. We will, therefore, follow Lamont's approach and attempt to find a viable proxy that would sufficiently closely predict the existence of shortages. Given the institutional arrangements of fuel distribution in Iraq, we think that the administered prices for fuel products could serve as a reasonable (inverse) proxy for shortages. The empirical evidence presented below tends to confirm this.

In addition to the link between fuel shortages and fuel price increases, there is also likely to be a relationship between fuel prices and core inflation, as shown in Humpage and Pelz (2002). The strength of the transmission channel from oil shortages to prices of non-oil goods will eventually depend on the ability of the private sector in Iraq to substitute between oil and other inputs of production and distribution of non-oil goods. We expect that the security situation in Iraq at the time would have limited the extent of this substitution.

To model core and non-core inflation dynamics, we consider two sectors of the Iraqi economy: production and distribution of (domestic and imported) fuel products and the nonoil economy. In the first sector, the monopolist faces two prices: the administered price set by the central government and the black market price at which he could potentially sell fuel products, if he could suppress the supply of fuel products and create a shortage. The costs for the monopolist are the administered prices of fuel since this is the amount that needs to be transferred to the budget for every liter of fuel sold. The black market price is his revenue. The imported price of fuel is irrelevant for the monopolist because this was actually paid for by the government. The difference between the administrated price and the black market price times the quantity of fuel sold is the potential rent for the monopolist.

The monopolist's objective function is thus presented as follows:

$$
\text { Rent }=\text { Revenue }- \text { Cost }=D(Q) \cdot Q-P_{a} \cdot Q,
$$

where $D(Q)$ is the (downward-slopping) inverse demand curve for oil products sold at any quantity $Q$ and $P_{a}$ is the administered price of goods (Figure 4). Maximizing equation 1 with respect to $Q$ produces the following first-order condition:

$$
(D(Q) \cdot Q)^{\prime}=P_{a} .
$$

The term on the left is the marginal revenue curve of the monopolist, $M R(Q)$. Equation 2 implies that the monopolist supplies the market with products until his marginal revenue equals the administered price (i.e., his marginal cost). The implication of this condition - and a reflection of the power of the monopolist to remain off the demand curve-is that the market would be forced to operate at $\left(Q_{a}, P_{b m}\right)$ combination of output and price, where $P_{b m}$ is the black market price. The rent that the monopolist would collect is equal to the difference between the black market prices and the administered prices for every unit of fuel products sold (the shaded area in Figure 4). Note that $P_{b m}$ is still below the international price of fuel products, $P^{*}$, because it is more profitable for the monopolist to operate at $\left(Q_{a}, P_{b m}\right)$ rather 
than at $\left(Q^{*}, P^{*}\right)$, even though the latter combination has a higher price. Indeed, if it was not for the strategic motivation of the monopolist to manipulate supply, black market prices would have been at $P^{*}$ all the time.

Figure 4. Basic Incentive Set-up of the Monopolist

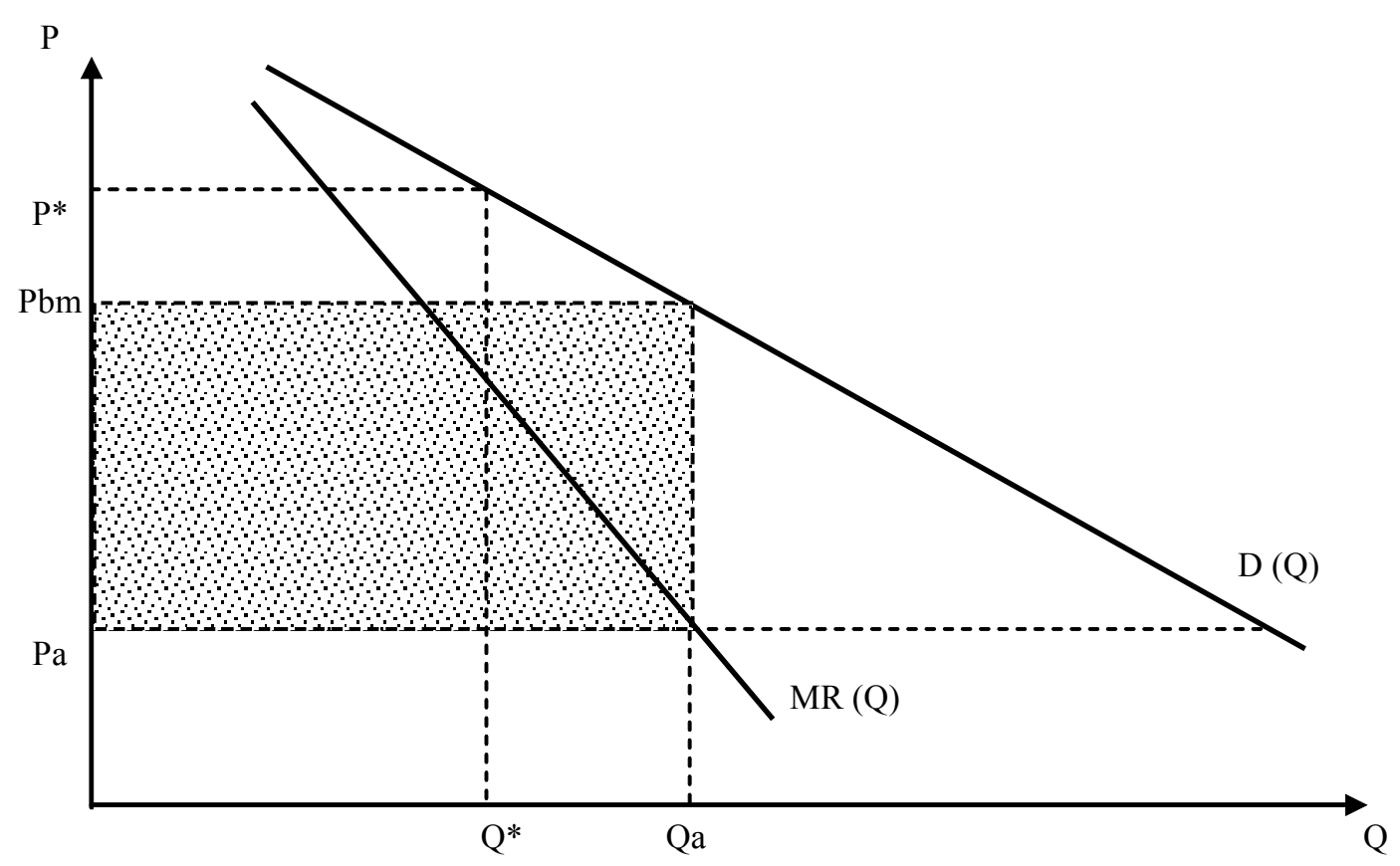

The horizontal difference between the demand and marginal revenue curves at $P=P_{a}$ [and between the demand curve and $Q_{a}$ at any price $\left.P \in\left(P_{a}, P_{b m}\right)\right]$ represents the supply shortage. The shortage becomes zero at $P=P_{b m}$. An important corollary to this basic set up is that, other things being equal, higher administrative prices are associated with smaller shortages. This is the result of falling demand and the resulting shrinking room for the monopolist to maneuver. Also, the model suggest that higher administrative fuel prices, and hence lower potential rents, will lead to less shortages, which is consistent with actual developments in Iraq in the period 2006-08.

To sum up, in the presence of monopolistic behavior, at any administered price there will be a shortage of fuel, which would drive the black market price upwards to eventually clear the market. The one exception, when black market prices converge toward international prices $\left(P_{b m}=P^{*}\right)$, is discussed below.

\section{Response to Administered Price Adjustments}

Figure 5 illustrates the response of the black market prices and quantities supplied to the market to an upward adjustment in the administered prices from $P_{a}$ to $P_{a}^{\prime}$. Consistent with equation 2 , the monopolist will reduce the quantity of fuel products supplied to the market along the marginal revenue curve. As a result, black market prices would increase to 
reach $P_{b m}^{\prime}>P_{b m}$, with fuel shortages declining as the difference between the demand and marginal revenue curves shrinks.

Figure 5. Response to Administered Price Adjustments

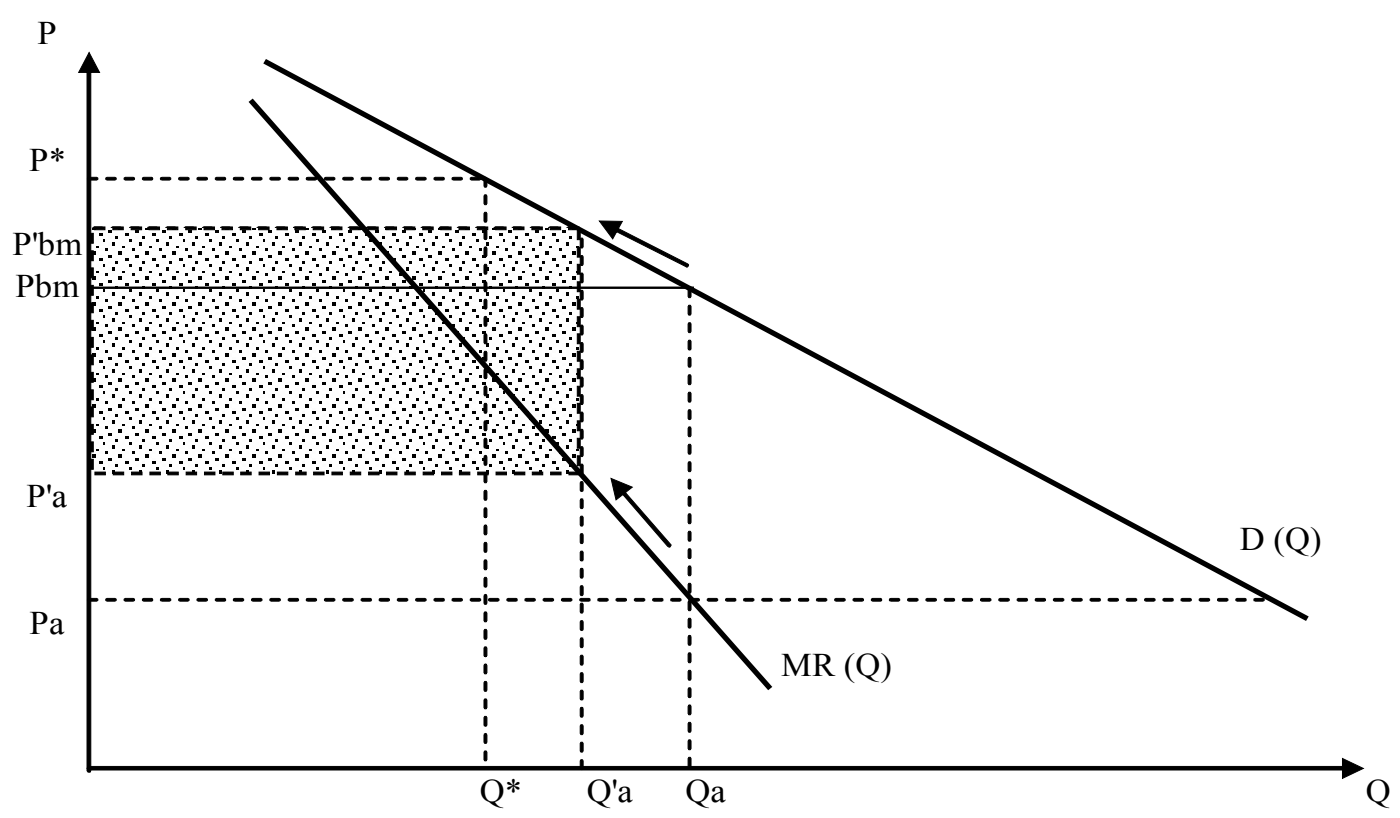

Once the administered price is high enough (at $P_{a}^{\prime \prime}$ ) so that the corresponding black market price reaches the international level, $P_{b m}^{\prime \prime}=P^{*}$ (point B, Figure 6), the monopolist has no incentives to further reduce supply, since he no longer has the ability to charge more by providing less to the market. At that point his ability to do so would be undercut by smuggling of fuel products from neighboring countries. Therefore, beyond the point of administered prices where the black market price is at $P_{b m}^{\prime \prime}=P^{*}$ (i.e., at any administered price $P^{*} \geq P_{a} \geq P_{a}^{\prime \prime}$ ), subsequent official price adjustments would result in the supply of fuel products remaining at $Q^{*}$, with the monopolist's overall rent collection being at $\left(P^{*}-P_{a}\right) \cdot Q^{*}$.

In a static world with complete information and constant international price $P^{*}$, administered prices could be increased up to a point where they are equal to $P^{*}$, allowing the market to clear at point $\mathrm{C}$ in Figure 6 . There will be no shortages at that point and the monopolist will generate no rents. In the real world, however, unless the administered prices are constantly adjusted in line with changing international prices, there will be room for the monopolist to capture rents, create shortages (with subsequent inflationary implications), and for the economy as a whole to accrue deadweight loses from the monopolistic behavior. 
Figure 6. Limits of Administered Price Adjustments

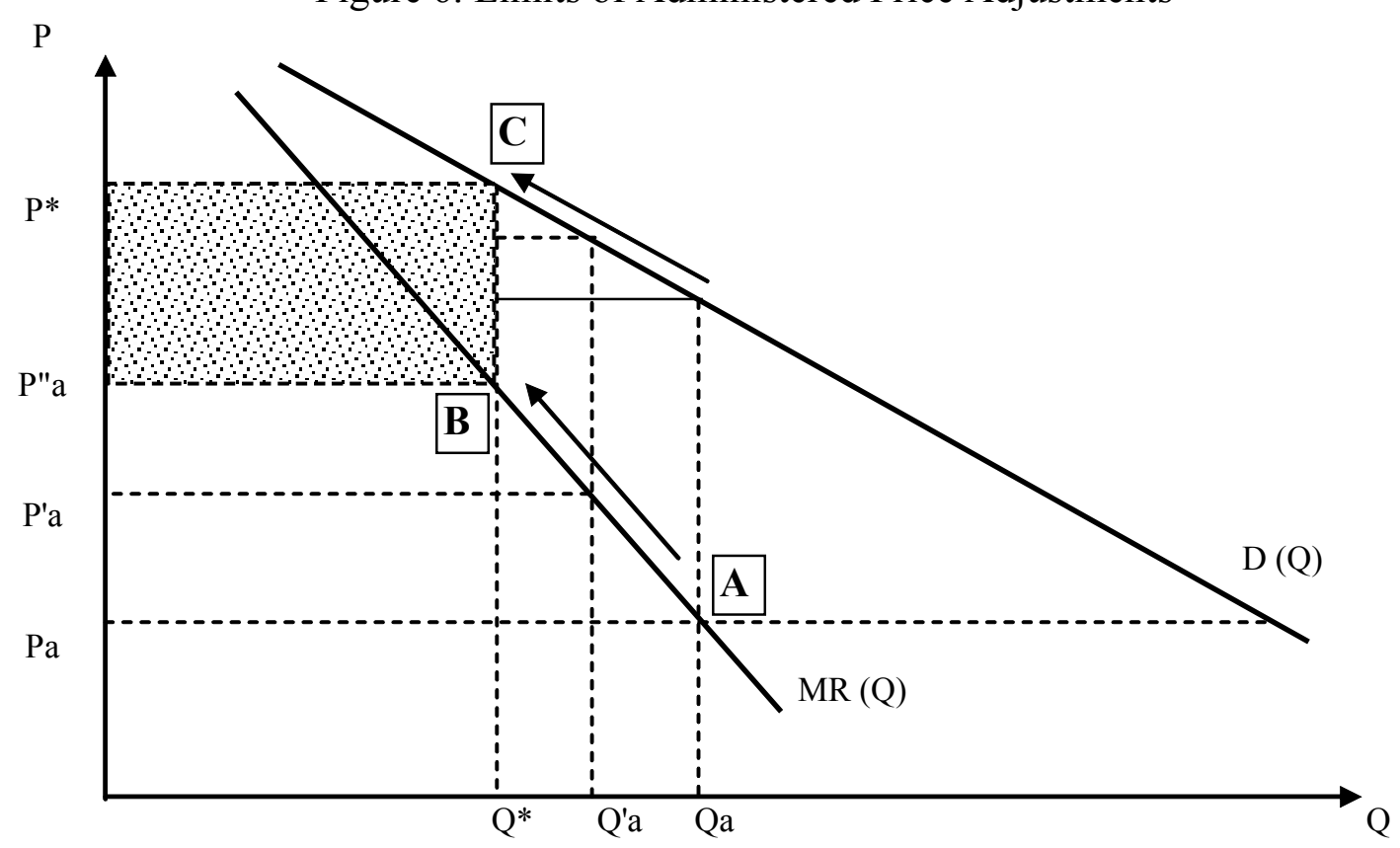

The administered approach to price adjustments (from A to B to C) requires continuous adjustment of administered prices to reach market clearing and limit rent seeking at all times. In reality, however, continuous adjustment of administrative prices is unworkable and even frequent adjustment of administrative prices will not eliminate shortages because the incentive of the monopolist to manipulate supply is restored every time when international prices deviate from administrative prices. Instead, full liberalization of the fuel market to allow private sector imports will always keep the market at an (adjustable) point $\mathrm{C}$, and will help eliminate deadweight loses. From a practical point of view, this may require implementing a one-time administrative adjustment to reach the international price level. From that point on, however, the government will have to take upon itself a different function of monitoring the fuel market to prevent collusions and any other forms of strategic price-setting behavior by the private sector participants.

Fuel shortages can also have implications for the non-oil economy. As demonstrated above, in response to an increase in administered prices for fuel products the quantity supplied declines, resulting in a shortage, which pushes up the black market price. A combination of higher fuel prices (both administered and black market) as well as their availability will drive up the prices of non-oil products (à la Humpage and Pelz, 2002). These two effects can be reinforcing, however. Assuming a simple Leontieff-type technology, it can be shown that quantity of fuel products supplied (constrained in this case by rent-seeking and violence) can have an additional impact on production and distribution of non-oil goods, beyond that suggested by the increase in the administered price for fuel products. ${ }^{16}$

\footnotetext{
${ }^{16}$ The assumption of a Leontieff-type technology for production (and distribution) of non-oil goods is plausible here given that the technology is fixed in the short run and is unlikely to change drastically given the security situation.
} 
In sum, the predictions of the model are as follows:

- $\quad$ Prior to adjusting the administered prices, the market is in an equilibrium, with black market prices stable and determined by the level of administered prices and the monopolist's marginal revenue schedule;

- In response to an increase in administered prices, the monopolist reduces the supply of fuel products to the market. Although demand also falls in response to the new price, black market prices for fuel products are pushed up. This drives a wedge between headline and core inflation measures;

- In the limit, where administered prices are raised to the same level as international prices, shortages will disappear because the monopolist no longer has an incentive to restrict supply of fuel products since his costs (the administered prices he pays to the central budget) equal his potential revenues;

- Depending on the nature of the production process, reduction in the supply of oil or higher (black market) prices will create supply bottlenecks for the production and distribution of non-oil products, resulting in higher core inflation.

\section{EMPIRICAL INVESTIGATION}

\section{A. Empirical Evidence}

It appears that the above model is able to explain the stylized facts outlined in Section II. First, the model predicts that when there are no changes in administered prices, the black market price for fuel remains constant, despite movements in international prices. In other words, when administered prices are stable, core inflation will be broadly in line with headline inflation. Once the administered price adjustments are introduced, however, black market prices will increase, generating fuel price inflation and driving a wedge between headline and core inflation. This is consistent with stylized fact 1.

Second, the model correctly predicts the level of the black market prices vis-à-vis international prices. While increasing in response to administered price adjustments, the black market prices for fuel products have remained below international/regional prices at all times (Figure 7). This is consistent with stylized fact 2 above.

Third, the model predicts that black market prices will not increase as much as the underlying administered price adjustments, leading to a decline in monopoly mark-ups or black market premia. (This is due to the fact that the marginal revenue curve is sloped twice as steep as the demand curve. See Figure 6 for comparative statics). This is consistent with stylized fact 3.

Fourth, the model predicts that there will always be shortages of fuel products unless administered prices are raised to the level of international prices. This is consistent with stylized fact 4 . The model also predicts that liberalizing the fuel market by allowing private 
sector imports may help eliminate shortages stemming from misalignment between international and administered prices.

Figure 7. International and Iraqi Black Market Prices for Gasoline

(U.S. dollar cents per liter), January 2005-March $2007^{17}$

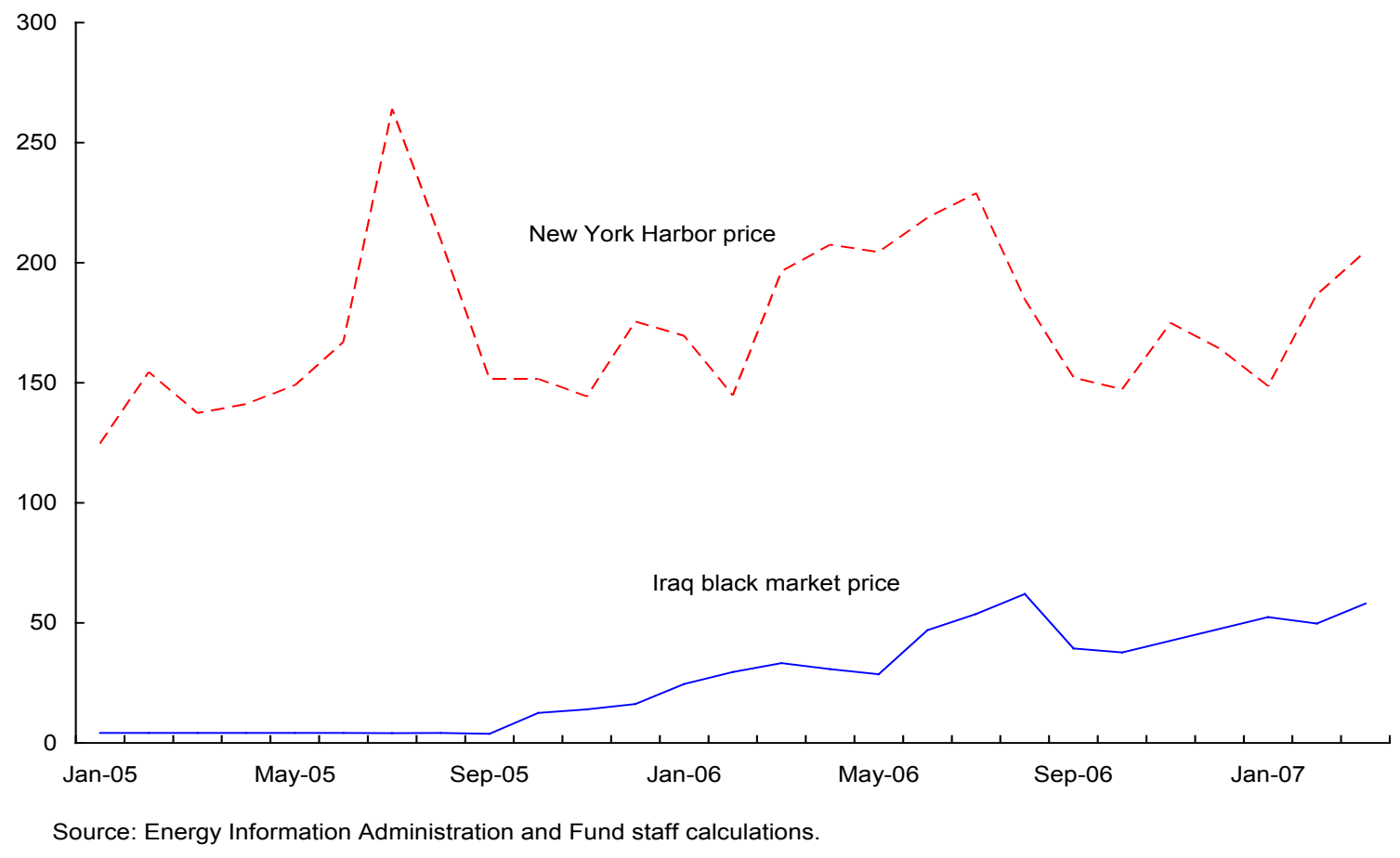

It turns out that the available data fit the model well. To demonstrate this we constructed the marginal revenue curve of the monopolist. ${ }^{18}$ The (implied) demand curve was then derived, drawing on the relationship between the demand and the marginal revenue schedules, and we plotted the black market prices. Note that, as predicted by the model, any combinations of administered prices and quantity of fuel sold observed in the data are those on the marginal revenue curve (and not on the demand curve), while the black market prices for fuel products will be located along the demand curve at any quantity sold. It appears that the model does reasonably well in predicting the location and the movement of the black market prices in response to administered price adjustments. As shown on Figure 8, following the adjustment of gasoline prices to ID 175 per liter in June 2006, the amount supplied to the market dropped to 14.8 million liters per month, with the black market price jumping to ID 710 per liter. The model's own prediction of that black market price-located on the imputed demand curve - appears to be very close at around ID 650 per liter.

\footnotetext{
${ }^{17}$ Data before 2005 are considered unreliable and are, therefore, not reported.

${ }^{18}$ The marginal revenue curve is based on equation 2 . We assume a second order quadratic specification to fit the data better.
} 
Figure 8. Prices and Quantities of Regular Gasoline

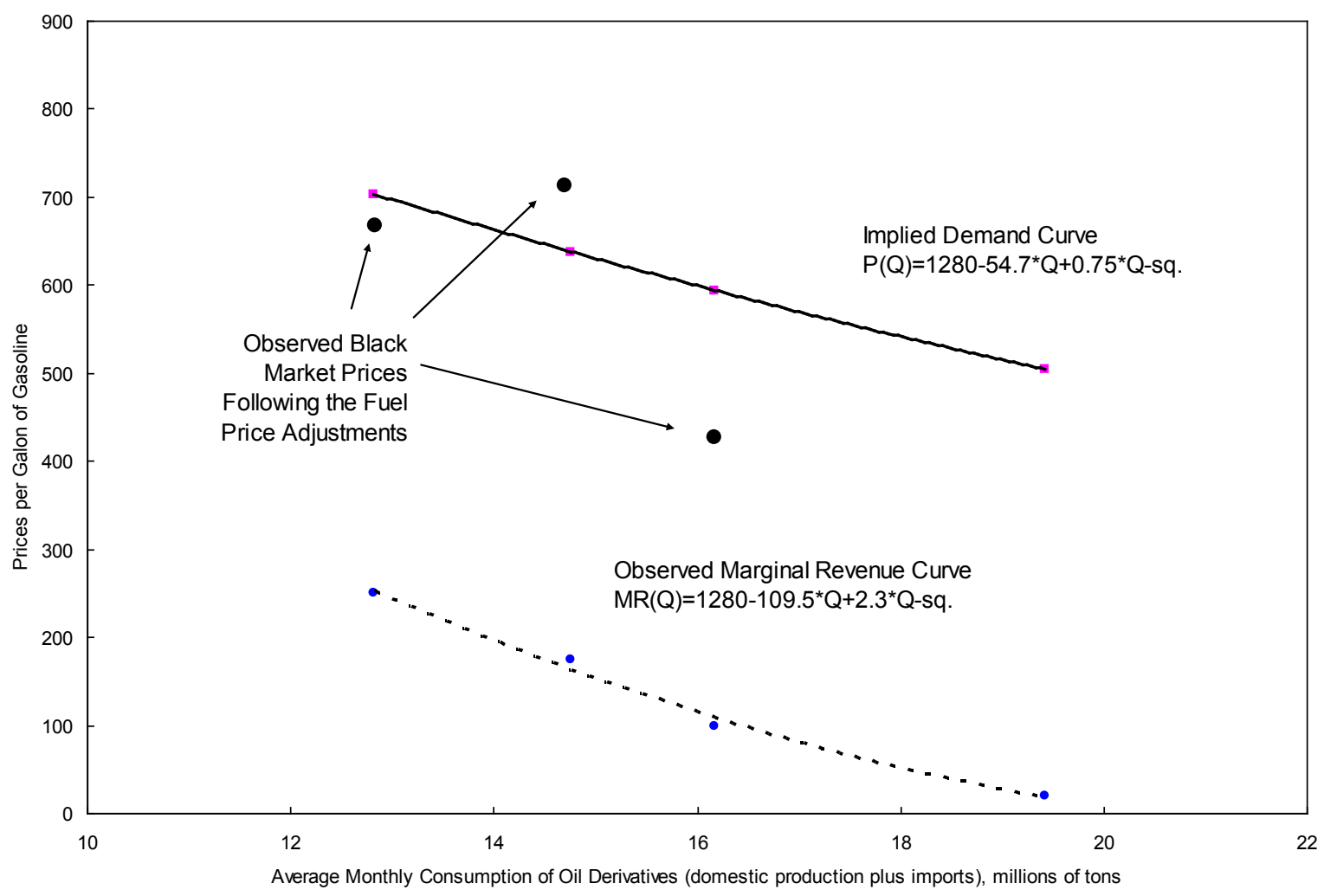

B. Econometric Evidence

To further test our model, we employ a simple econometric model to explain headline and core inflation in Iraq. We divide the determinants of inflation into two groups: conventional and unconventional. Consistent with the empirical literature (e.g., Lissovolik (2003), Liu and Adedeji (2000), Ubide (1997), among others), we included measures of monetary, fiscal and exchange rate policies as conventional determinants. ${ }^{19}$ The second set of indicators includes an indicator of violence and a proxy for shortages. As discussed above, the shortages can be due either to security-related factors or be the result of monopolistic behavior in fuel distribution. Violence can also impact non-oil market developments. For simplicity, the estimated equation can be shown in the following additive fashion:

$$
P=\left[S_{O}+V\right]+[M+G+E]
$$

The terms in the first set of brackets - proxy for oil shortages, and violence indicator, $V$ represent the supply side bottlenecks that affect prices in the oil and non-oil sectors. As discussed above, we use the administered prices for fuel products as an inverse proxy for

\footnotetext{
${ }^{19}$ Due to lack of suitable proxies with monthly frequency we did not include any measures of economic activity in the regressions. (Data comprising Iraq's GDP are poorly measured and are only available on an annual basis). This omission is likely to have only minor implications, given the short period under review.
} 
shortages. ${ }^{20}$ We use the number of troops killed and the number of civilians killed as proxies for violence. ${ }^{21}$ The terms in the second set of brackets - reserve money, $M$, as a proxy for the money supply, ${ }^{22}$ the government wage bill $G$, as a proxy for fiscal spending, and the exchange rate, $E$, - are proxies for the demand side pressures. We also included seasonal dummies in the regressions. Both measures of inflation $P$, headline and core, were used. A description of the data and sources is in the Appendix.

Equation 3 was estimated using month-on-month percentage change of the relevant price indexes for the period of January 2004 through March 2007. ${ }^{23} 1-3$ lags of each indicator were used to arrive at the final specifications. Due to the short length of the time series and the underlying unstable economic environment in Iraq, the econometric estimates should be treated with caution.

The results, reported in Table 3, however, are consistent with expectations and shed some additional light on the above discussion. They can be summarized as follows:

- $\quad$ As expected, the proxy for fuel shortages appears to be a strong predictor of headline inflation, but not of core inflation, thus explaining the wedge between headline and core inflation. Also consistent with the prediction on the importance of quantity of fuel supplied in the non-oil sector, the quantity of gasoline available on the market is a strong predictor of core inflation.

- There is evidence that violence is associated with higher inflation. However, the link is mostly with core inflation, indicating a stronger effect of violence on nonfuel commodity supplies than on fuel commodity supplies.

- $\quad$ Despite the relatively stable path of the exchange rate for most of the period in question, it has a strong positive impact on prices, both headline and core. The estimates suggest that a 10 percent appreciation is likely to result in almost 8 percent reduction of headline inflation, and 6-7 percent of reduction of core inflation. If Iraq's real exchange rate was indeed appreciating gradually to a new

\footnotetext{
${ }^{20}$ Note that the administered prices have a relatively small weight in the calculation of the fuel price index in Iraq (26 percent, with the remainder being accounted for by black market prices), which itself has only a 2.1 percent weight in the overall basket, and are unlikely to serve as true price/reference point for fuel products for the vast majority of market participants. This should limit the risk of direct collinearity between administered prices and inflation measures.

${ }^{21}$ Chaney (2008) uses the same indicators as control variables in an analysis that uses the variation in the Iraqi sovereign bond spreads to evaluate pacification policy in Iraq.

${ }^{22}$ To the extent that the exchange rate has been kept fixed for most of the period under review (and the capital account is free), it is possible that the money supply was endogenously determined by nominal income/prices, rather than the other way around. Absent reliable and long time series on income measures, we could not test this in the context of this study. We do, however, expect that lagging the reserve money should reduce the extent of this endogeneity problem.

${ }^{23}$ Because of short time span of our observation period, all possible adjustments in the short run behavior of prices due to long-term misalignment in either the money or foreign exchange markets are very difficult to measure and have been assumed negligible.
} 
equilibrium, this strong pass-through from the exchange rate to inflation suggests that the strategy to allow the nominal exchange rate to appreciate since November 2006 to reduce inflation was justified.

- Money growth has a small but positive impact on both headline and core inflation. The results suggest that a 10 percent increase in reserve money would result in only 3 percentage points of additional inflation. ${ }^{24}$ This lends support to the assumption of a weak monetary transmission mechanism. It also points to an increase in real demand for money linked to the growth of the (non-oil) economy.

- $\quad$ The magnitude (and significance) of the constant (including seasonal dummies) in columns 3 and 4 -about 20 percent per annum for the observation period or roughly $3 / 4$ of the average monthly core inflation-suggests that there is a persistent underlying trend in core inflation. In light of the de facto pegged nominal exchange rate for most of the period under review, this could well be due to the adjustment of the real exchange rate to a new, higher equilibrium level as discussed above, or supply-side adjustments (e.g., catching up).

- The results did not reveal a significant impact of fluctuation in the government's wage and pension bill (a proxy for the overall fiscal stance) on inflation, and we have dropped this variable from our final estimation results. However, this may mean that fluctuations in fiscal spending have not been inflationary and does not necessarily imply that the fiscal stance did not have an impact on the core rate of inflation. Moreover, this result could reflect mismeasurement of the true fiscal stance, which should perhaps include other components of current spending as well as capital outlays, particularly those elements that impact the domestic economy. ${ }^{25}$ Subsequent research could attempt to look at the impact of the level of fiscal spending on inflation dynamics.

- $\quad$ There seems to be a strong seasonality present in inflation, especially headline inflation. Headline inflation in the fourth quarter of each year was 4 percent higher (month-on-month) by comparison to other quarters, other things being equal. ${ }^{26}$ This is consistent with the timing of Ramadan, which fell in the final quarter of each year during 2004-06. The inability of supply — of both oil and non-oil products - to catch up with demand during Ramadan (thus generating sizable price hikes), provides indirect evidence of the existence of supply bottlenecks.

\footnotetext{
${ }^{24}$ Despite the cash-based nature of most transactions, dinar currency in circulation turned out not to be a significant explanatory variable for inflation. This could have been an outcome of widespread dollarization (and a resulting understatement of true cash balances held by population as conjectured above), which in the period under review was fuelled by cash disbursements by coalition troops and reconstruction teams.

${ }^{25}$ Measuring the domestic component of the fiscal envelope proved impossible.

${ }^{26}$ The signs of the quarterly dummies in the equations of core inflation indicate that inflation is higher in Q1, by about 2 percent, which could reflect a longer pass-through from supply to price adjustments for food and other non-fuel products than for fuel products.
} 
- $\quad$ There appears to be no path dependency in inflation during the observed period.

Table 3. Regression Results

\begin{tabular}{|c|c|c|c|}
\hline & \multicolumn{3}{|c|}{ Dependent Variable: month-on-month percent change in: } \\
\hline & Headline Inflation & Core Inflation & Core Inflation \\
\hline Constant & $\begin{array}{r}0.02 \\
(1.02)\end{array}$ & $\begin{array}{r}0.03 * * \\
(2.80)\end{array}$ & $\begin{array}{r}0.02 * * \\
(2.61)\end{array}$ \\
\hline Lagged dependent variable & $\begin{array}{r}-0.19 \\
(-1.24)\end{array}$ & $\begin{array}{r}0.21 \\
(1.41)\end{array}$ & $\begin{array}{r}0.15 \\
(1.40)\end{array}$ \\
\hline Exchange Rate & $\begin{array}{r}0.81 * * \\
(2.48)\end{array}$ & $\begin{array}{r}0.71 * * \\
(3.91)\end{array}$ & $\begin{array}{r}0.57 * * \\
(4.25)\end{array}$ \\
\hline Reserve money & $\begin{array}{r}0.36^{* *} \\
(3.20)\end{array}$ & $\begin{array}{r}0.25^{* *} \\
(3.31)\end{array}$ & $\begin{array}{r}0.26^{* *} \\
(4.90)\end{array}$ \\
\hline Administered price for gasoline & $\begin{array}{r}0.09^{* *} \\
(2.84)\end{array}$ & $\begin{array}{r}0.01 \\
(0.47)\end{array}$ & \\
\hline Supply of gasoline & & & $\begin{array}{c}-0.04^{*} \\
(-1.79)\end{array}$ \\
\hline Civilians killed & $\begin{array}{r}0.04 \\
(1.54)\end{array}$ & & \\
\hline Troops killed & & $\begin{array}{r}0.03 * * \\
(2.41)\end{array}$ & $\begin{array}{r}0.02 * * \\
(2.41)\end{array}$ \\
\hline Q2 & $\begin{array}{r}-0.03 \\
(-1.14)\end{array}$ & $\begin{array}{r}-0.03 * * \\
(-2.35)\end{array}$ & $\begin{array}{c}-0.02 * \\
(-1.98)\end{array}$ \\
\hline Q3 & $\begin{array}{r}-0.02 \\
(-0.66)\end{array}$ & $\begin{array}{l}-0.03 * \\
(-1.84)\end{array}$ & $\begin{array}{r}-0.02 \\
(-1.57)\end{array}$ \\
\hline Q4 & $\begin{array}{c}0.04 * \\
(1.76)\end{array}$ & $\begin{array}{r}-0.01 \\
(-0.98)\end{array}$ & $\begin{array}{r}0.00 \\
(-0.35)\end{array}$ \\
\hline R-squared & 0.46 & 0.58 & 0.70 \\
\hline Mean dependent variable & 0.03 & 0.02 & 0.02 \\
\hline F-statistic & 3.17 & 5.20 & 8.62 \\
\hline Prob(F-statistic) & 0.01 & 0.000 & 0.000 \\
\hline No. of obs. & 39 & 39 & 38 \\
\hline
\end{tabular}

Note: OLS estimates. t-statistics in parenthesis. ${ }^{* *}$ and $*$ indicate significance at 5 and 10 percent level, respectively.

\section{Conclusions ANd Policy Implications}

Since the invasion in 2003, inflation in Iraq has been high, and in 2006 it increased sharply. Our findings show that inflation may have been influenced by shortages in fuel and non-fuel commodity supplies themselves driven by violence and rent-seeking behavior in the fuel distribution sector. We also conjecture that trend inflation may have been influenced by 
adjustment of the real exchange rate to a new (appreciated) equilibrium in the context of improved terms of trade and a fixed exchange rate.

The results also suggest that, while raising administered fuel prices may contribute to inflation in the short run, raising such prices to international levels would eliminate rentseeking via induced shortages, and thereby help reduce inflation. The fuel monopolist has an incentive to engage in behavior that is socially sub-optimal by suppressing the supply of oil products and keeping it below market equilibrium levels.

Given the focus on supply shortages as a factor in driving inflation in Iraq, the findings also provide strong support for the authorities' policy of liberalizing the importation and distribution of fuel products and allow the private sector to freely operate in this sector. Adjusting fuel prices closer to international levels helps in reducing shortages but does not change the underlying incentives of the fuel monopolist to maximize and collect rent by supplying less than what the market could consume at any given price. It is clear that full convergence of both prices and quantities towards the equilibrium levels will be achieved through liberalization of the supply network to allow the private imports of gasoline. These policies have helped reduce inflation from 65 percent at end-2006 to single digits in the last quarter of 2008.

The econometric results presented in the paper also highlight the important role that the continuing violence has played in hindering efforts to reduce inflation. The effect of violence is stronger for non-fuel commodity supplies than for fuel commodity supplies.

Finally, the result shows a strong pass-through from the exchange rate to inflation which supports the government's policy of a gradual appreciation of the exchange rate to control inflation. 


\section{APPENDIX I: DESCRIPTION OF VARIABLES}

Our sample includes monthly data between January 2004 and March 2007. Although data availability for Iraq has improved in recent years, problems with methodology and limits of coverage remain. We acknowledge these data limitations as potentially influencing the robustness of our estimates.

- Core inflation excludes fuel and transportation prices. The data is collected on a monthly basis by Iraq's Central Organization for Statistics and Information Technology (COSIT) and reported by the Central Bank of Iraq (CBI).

- Exchange rate between the Iraqi dinar and the U.S. dollar. The new Iraqi dinar was introduced in late 2004 and until November 2006 the rate of exchange had de facto been pegged. The exchange rate has been allowed to appreciate since then. Reported by the CBI.

- Currency in circulation is the amount of dinars in circulation outside the banking system. Reported by the CBI.

- $\quad$ Reserve money is the (dinar) currency in circulation plus reserves held by banks with the CBI. Reported by the CBI.

- Wage bill is the total wage and pension bill of the central government. Reported by the Ministry of Finance.

- Supply of gasoline is the total volume of imported and domestically produced gasoline supplied to the Iraqi market. Data are reported by the Word Bank based on information obtained from the Iraqi Ministry of Oil.

- Administered price is the price for regular gasoline set by the government. These prices were increased according to the following schedule (prices per liter): ID 100 in December 2005, ID175 in June 2006, ID 250 in December 2006, ID 300 in March 2007, and ID400 in July 2007.

- Civilians killed is the monthly average number of civilians killed per day in hostile action. Data are reported by Iraq Body Count (IBC) non-governmental organization (Available from: http://www.iraqbodycount.org/). Average of the upper and lower count provided by IBC was used.

- Troops killed is the average number of coalition troops killed per day. Only soldiers killed in combat are reported. The data is provided by the NGO Iraq Coalition Casualty Count (Available from: http://icasualties.org/oif/). 


\section{References}

Berman, E., J. Shapiro, J. Felter, 2008. Can hearts and minds be bought? The economics of counterinsurgency in Iraq, NBER Working Paper Series, No. 14606.

Chaney, E., 2008. Assessing pacification policy in Iraq: Evidence from Iraqi financial markets, Journal of Comparative Economics, Vol. 36, pp. 1-16.

Foote, C., W. Block, and S. Gray, 2004. Economic policy and prospects in Iraq, The Journal of Economic Perspectives, Vol. 18, No. 3, pp. 47-70.

Humpage, O. and E. Pelz, 2002. "Do Energy-Price Shocks Affect Core-Price Measures?" Federal Reserve Board of Cleveland Working Paper No. 02/15, Cleveland, Ohio.

International Monetary Fund (IMF), 2007. Iraq: 2007 Article IV Consultation, country report 07/301, Washington, DC.

King, M., 2004. “The institutions of monetary policy”, American Economic Review, May 2004, pp. 1-13.

Lamont, O., 1995. “Do 'Shortages' Cause Inflation?” NBER Working Paper 5402, National Bureau of Economic Research, Cambridge, Massachusetts.

Liu, O. and O. Adedeji, 2000. Determinants of Inflation in the Islamic Republic of Iran: A Macroeconomic Analysis, IMF Working Paper No. 00/127, Washington, DC.

Lissovolik, B., 2003. Determinants of Inflation in a Transition Economy: the Case of Ukraine, IMF Working Paper No. 03/126, Washington, DC.

Office of the Inspector General, 2006. "Smuggling Crude Oil and Oil Products: Second Transparency Report," Ministry of Oil, Iraq. Available via http://lugar.senate.gov/iraq/pdf/13_MOI_IG_report.pdf.

Rowat, C., 2008. "The Iraqi petroleum subsidies: transfers and remidies to the free cash flow problem?”, Energy \& Development Occasional Papers, Iraq Energy Institute.

Shleifer, A. and R. Vishny, 1992. Pervasive Shortages under Socialism, The RAND Journal of Economics 23, No. 2, pp. 237-246.

Ubide, A. J., 1997. “Determinants of Inflation in Mozambique,” IMF Working Paper No. 97/145, Washington, DC. 